\title{
Exhaust gas treatment for reducing cold start emissions of a motorcycle engine fuelled with gasoline-ethanol blends
}

\author{
A Samuel Raja
}

\author{
A Valan Arasu \\ Department of Mechanical Engineering, Thiagarajar College of Engineering, Madurai, Tamilnadu, India
}

\begin{abstract}
In countries like India, transportation by a two wheeled motorcycle is very common owing to affordable cost, easy handling and traffic congestion. Most of these bikes use single cylinder air cooled four-stroke spark ignition (SI) engines of displacement volume ranging from $100 \mathrm{~cm}^{3}$ to 250 $\mathrm{cm}^{3}$. CO and $\mathrm{HC}$ emissions from such engines when started after a minimum stop-time of 12 hours or more (cold-start emissions) are higher than warmed-up emissions. In the present study, a 150 $\mathrm{cm}^{3}$ single cylinder air cooled SI engine was tested for cold start emissions and exhaust gas temperature. Different gasoline-ethanol blends (E0 to E20) were used as fuel expecting better oxidation of $H C$ and $\mathrm{CO}$ emissions with additional oxygen present in ethanol. The effect of glow plug assisted exhaust gas ignition (EGI) and use of catalytic converter on cold start emissions were studied separately using the same blends. Results show that with gasolineethanol blends, cold start $\mathrm{CO}$ and $\mathrm{HC}$ emissions were less than that with neat gasoline. And at an ambient temperature of $30 \pm 1^{\circ} \mathrm{C}$, highest emission reductions were observed with E10. EGI without a catalytic converter had no significant effect on emissions except increasing the exhaust gas temperature. The catalytic converter was found to be active only after 120 seconds in converting cold start CO, $\mathrm{HC}$ and $\mathrm{NO}_{\mathrm{x}}$. Use of a catalytic converter proves to be a better option than EGI in controlling cold start emissions with neat gasoline or gasoline-ethanol blends.
\end{abstract}

Keywords: cold start, gasoline-ethanol blends, exhaust gas ignition, glow plug

\section{Introduction}

Emissions from an internal combustion engine, started after a minimum halt time of 12 hours or more, are known as cold start emissions (Favez et al., 2009). Carbon monoxide (CO) and unburnt hydrocarbon $(\mathrm{HC})$ are emitted in larger quantities during the first few minutes of a spark ignition (SI) engine with cold start because of the inactive or less active catalytic converter (Iliyas et al., 2007). The catalytic conversion is more effective only after the catalyst reaches its light-off temperature which is above $150^{\circ} \mathrm{C}$ (Singer et al., 1999). The time period required for the catalyst to reach its light-off temperature is referred to as cold-start period or unstable engine running period. In water cooled engines, stable engine operation is achieved at coolant temperature of about $70^{\circ} \mathrm{C}$ and it may take 6 to $7 \mathrm{~min}$ utes of the engine running after cold start (Botsaris et al., 2003). In air cooled SI engines, stable engine operation is achieved earlier than water cooled SI engines due to higher exhaust temperatures resulting from less effective cooling by air. The test engine in the current work is a single cylinder air cooled engine and hence cold start emissions and exhaust temperature have been recorded for the first four minutes after a cold start.

Generally, engine-out emissions are controlled in any one or two or all of the three techniques namely fuel modification, engine modification and exhaust gas treatment. Fuel modification (gasolineethanol blends) and exhaust gas treatment (exhaust gas ignition and catalytic converter) are attempted in the current work. Considering fuel modification for SI engines, gasoline-ethanol blends have been reported as a suitable alternate fuel for neat gasoline by various researchers (Pourkhesalian et al., 2010; Bayraktar, 2005; Eyidogan et al., 2010) all over the world. The two factors that make gasolineethanol blends suitable for S.I. Engines are the presence of an oxygen atom in the fuel structure of ethanol and a higher octane number of ethanol 
than that of gasoline. According to different researchers (Balki et al., 2012; Masum et al., 2013; Canakci et al., 2013), the optimum blend may contain 5 percent ethanol to 20 percent ethanol. This variation is due to difference in the experimented parameters such as compression ratio, ignition timing, engine load and speed. In the current work, no modification was made in the compression ratio and ignition timing. Ethanol was blended with gasoline in 5, 10, 15 and 20 percent by volume and the blend is correspondingly named E5, E10, E15 and E20. The RVP (Reid Vapour Pressure) of ethanol is $17 \mathrm{kPa}$, far lower than $53.7 \mathrm{kPa}$ for gasoline. But their mixture does not have an RVP value linearly proportional to the volume fraction. A volume fraction of 5 to $10 \%$ ethanol can achieve the maximal RVP and thus facilitate cold-start (Thring, 1983). On account of higher latent heat of vaporization of ethanol, poor cold start performance has been observed with such blends when used in a water cooled engine (Turner et al., 2011; Clairotte et al., 2013). But with electronic fuel injection, the optimum percentage of ethanol in the blend for least cold-start emissions is reported to be at least 20 but not exceeding 30 (Chen et al., 2011). It is also reported that E10 blend results in higher acetaldehyde and ethanol emissions compared to neat gasoline (Poulopoulos \& Philippopolous, 2003).

In order to overcome the poor vaporization effect of ethanol, modifications in the engine such as heated intake air or/and heated intake fuel system have been attempted (Spegar et al., 2012; Sales \& Sodré, 2012; Raja \& Arasu, 2014). This modification has not only reduced cold-start $\mathrm{CO}$ and $\mathrm{HC}$ but also has increased exhaust gas temperature which enables the catalytic converter (if used) to reach its light-off temperature quicker.

Among various exhaust gas treatment techniques for SI engines, use of a catalytic converter is popular owing to its ability to convert the harmful $\mathrm{CO}, \mathrm{HC}$ and $\mathrm{NO}_{\mathrm{x}}$ emissions into $\mathrm{CO}_{2}, \mathrm{H}_{2} \mathrm{O}, \mathrm{O}_{2}$ and $\mathrm{N}_{2}$ in stable engine running conditions (Twigg, 2007). The substrate used in a catalytic converter can be ceramic or metallic. At low speeds, conversion of $\mathrm{HC}$ emissions is higher with a ceramic substrate whereas a metallic substrate behaves better at higher engine speeds and higher exhaust temperatures. But the substrate type has a less significant effect on $\mathrm{CO}$ or $\mathrm{NO}_{\mathrm{x}}$ conversion (Santos \& Costa, 2008). Among the various metals, Platinum (Pt), Palladium (Pd) and Rhodium ( $\mathrm{Rh}$ ) have been found to remain metallic and not to form volatile metallic oxides. Due to this reason, currently $\mathrm{Pt}$ or $\mathrm{Pd}$ is used for conversion of $\mathrm{CO}$ and $\mathrm{HC}$ emissions and $\mathrm{Rh}$ is used for conversion of $\mathrm{NO}_{\mathrm{x}}$ emissions (Twigg, 2006) in the present day catalytic converters. In the current work, a catalytic converter of metallic substrate loaded with $\mathrm{Pd}$ and $\mathrm{Rh}$ catalysts in the ratio of $37: 3$ $\mathrm{g} / \mathrm{ft}^{3}$ has been used.
To increase the catalyst surface temperature quickly to its light-off temperature, glow plugs installed at the front and at the middle of converter have been used to heat the metal substrate and hence the catalyst (Horng \& Chou, 2004). The results show that $\mathrm{CO}$ oxidation was higher with heating at inlet and at catalyst temperature of $180^{\circ} \mathrm{C}$.

Though adequate literature is available on the effect of gasoline-ethanol blends in water cooled engines, only a few references (Leong et al., 2002; Yang et al., 2005) are available for air cooled engines. Moreover, the effect of EGI or the effect of a catalytic converter in such engines fuelled with gasoline-ethanol blends, on cold-start emissions has not been addressed. The aim of the present work is to fill this gap and hence it focuses on the experimental study on the effect of EGI or use of a catalytic converter on cold-start emissions of an air cooled motorcycle engine fuelled with gasolineethanol blends.

\section{Experimental set-up and procedure}

A single cylinder air cooled motorcycle SI engine with specifications shown in Table.1 was used to conduct experiments which were conducted in three phases. In the first phase, cold start emissions and exhaust temperature were recorded for neat gasoline and gasoline ethanol blends without a catalytic converter and without exhaust gas ignition. These experiments were carried out to study the effect of gasoline-ethanol blends alone in the cold start emissions. In the second phase, experiments were done with the same fuels with exhaust gas ignition (EGI) using a glow plug. The glow plug was mounted after the exhaust port. The objective of this phase is to study the effect of EGI alone on cold start emissions. As a considerable percentage of two wheelers (manufactured before 2010) are still running on roads without a catalytic converter, these two sets of experiments were performed to study the effect of gasoline-ethanol blends and EGI on motorcycle engines equipped with no catalytic converter. To meet the stringent emission norms, from 2010 onwards, a 4-stroke motorcycle S.I. Engine is fitted with a catalytic converter. Hence, third phase of experiments was completed with the same fuel blends with a catalytic converter and without EGI to study the effect and behaviour of a catalytic converter alone on cold start emissions.

The exhaust pipe of the test engine was modified to accommodate a catalytic converter, glow plug, thermocouples and an exhaust gas sampling probe at the required locations and their positions are indicated in Figure.1. A time interval of 12 hours was given between each experiment to ensure a cold start. An idling speed of $1400 \pm 50$ rpm was maintained in all experiments. The fuel blends were prepared just before starting the exper- 


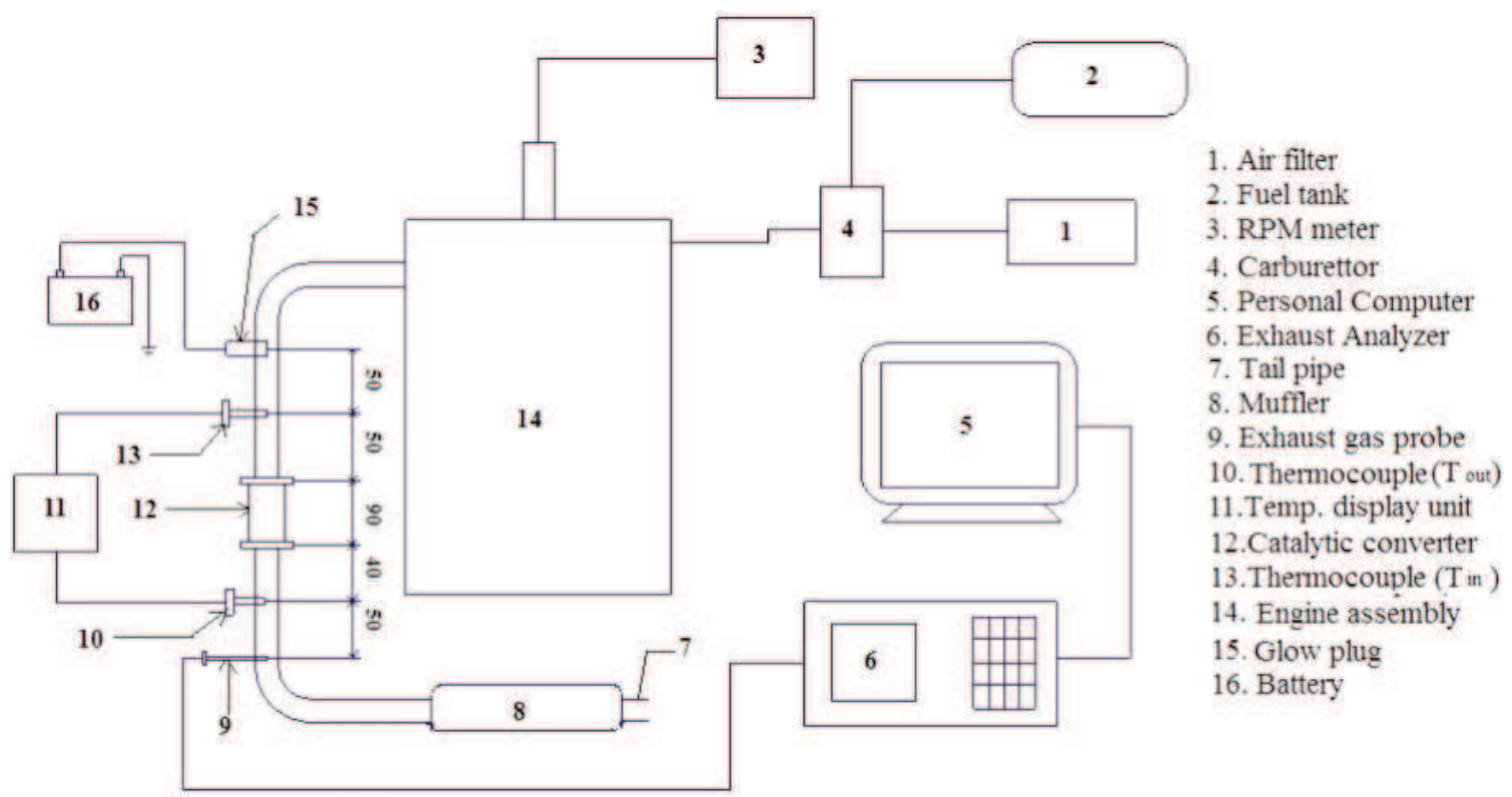

All dimensions are in $\mathrm{mm}$

Figure 1: Experimental set-up

Table 1: Engine specifications

\begin{tabular}{ll}
\hline Engine Type & Four-stroke, air cooled, single cylinder, SI Engine \\
\hline Bore x Stroke & $58 \mathrm{~mm} \times 56.4 \mathrm{~mm}$ \\
\hline Maximum power & $11 \mathrm{~kW} @ 8500 \mathrm{rpm}$ \\
\hline Maximum Torque & $12.76 \mathrm{Nm} @ 6500 \mathrm{rpm}$ \\
\hline Compression ratio & $9.5: 1$ \\
\hline Fuel supply system & Constant Vacuum carburettor \\
\hline Fuel & unleaded gasoline + anhydrous ethanol \\
\hline Idling speed & $1400 \pm 50 \mathrm{rpm}$ \\
\hline Valve timing & Intake opens $12.1^{\circ} \mathrm{CA}$ before TDC \\
\hline & Intake closes $55.5^{\circ} \mathrm{CA}$ after BDC \\
\hline & Exhaust opens $36.5^{\circ} \mathrm{CA}$ before BDC \\
\hline Ignition timing & Exhaust closes $14.1^{\circ} \mathrm{CA}$ after TDC \\
\hline & $9.1^{\circ} \mathrm{CA}$ before TDC
\end{tabular}

Table 2: Fuel properties

\begin{tabular}{lcc}
\hline Property & Gasoline & Ethanol \\
\hline Formula (liquid) & $\mathrm{C}_{8} \mathrm{H}_{18}$ & $\mathrm{C}_{2} \mathrm{H}_{6} \mathrm{O}$ \\
\hline Molecular weight $(\mathrm{kg} / \mathrm{kmol})$ & 114.15 & 46.07 \\
\hline Density $\left(\mathrm{kg} / \mathrm{m}^{3}\right)$ & 765 & 785 \\
\hline Heat of vaporization $(\mathrm{kJ} / \mathrm{kg})$ & 305 & 840 \\
\hline Specific heat $(\mathrm{kJ} / \mathrm{kg} \mathrm{K})$ Liquid & 2.4 & 1.7 \\
\hline Specific heat $(\mathrm{kJ} / \mathrm{kg} \mathrm{K})$ Vapour & 2.5 & 1.93 \\
\hline Lower Heating Value $(\mathrm{kJ} / \mathrm{kg})$ & 44,000 & 26,900 \\
\hline Stoichiometric air-fuel ratio by mass & 14.6 & 9.00 \\
\hline Research Octane Number & 92 & 108.6 \\
\hline Motor Octane Number & 85 & 89.7 \\
\hline Enthalpy of formation $(\mathrm{MJ} / \mathrm{kmol})$ Liquid & 259.28 & 224.10 \\
\hline Enthalpy of formation $(\mathrm{MJ} / \mathrm{kmol})$ Gas & 277.0 & 234.6 \\
\hline
\end{tabular}


iment to ensure that the fuel mixture was homogenous and no water was formed by reaction of ethanol with water vapour in the atmosphere. Properties of neat gasoline and neat ethanol are given in Table 2.

As the multiple attempts to start the engine affected the cold start emissions considerably, adequate care was taken to start the engine in the first attempt using the starter motor. Emissions were recorded for every two seconds for 4 minutes from the engine start by 5-gas analyser with specifications shown in Table 3 and the values were stored in a personal computer interfaced with an exhaust gas analyser. In the third phase of experiments, a new catalytic converter with specifications shown in Table 4 was used. Exhaust gas temperatures before and after the catalytic converter were measured using K-type thermocouples.

Table 3: Exhaust gas analyser specifications

\begin{tabular}{lccc}
\hline Gas & Range(by volume) & Accuracy & Resolution \\
\hline $\mathrm{CO}$ & 0 to $10 \%$ & $\pm 0.06 \%$ & $0.01 \%$ \\
\hline $\mathrm{HC}$ & 0 to $10000 \mathrm{ppm}$ & $\pm 12 \mathrm{ppm}$ & $1 \mathrm{ppm}$ \\
\hline $\mathrm{CO}_{2}$ & 0 to $20 \%$ & $\pm 0.5 \%$ & $0.1 \%$ \\
\hline $\mathrm{O}_{2}$ & 0 to $25 \%$ & $\pm 0.1 \%$ & $0.01 \%$ \\
\hline $\mathrm{NO}_{\mathrm{x}}$ & 0 to $2000 \mathrm{ppm}$ & $\pm 5 \mathrm{ppm}$ & $1 \mathrm{ppm}$ \\
\hline
\end{tabular}

Table 4: Catalytic converter specifications

\begin{tabular}{ll}
\hline Composition & $\mathrm{JM665/40/0:37:3}$ \\
\hline Catalyst loading & $40 \mathrm{~g} / \mathrm{ft}^{3}$ \\
\hline Platinum & $0 \mathrm{~g} / \mathrm{ft}^{3}$ \\
\hline Palladium & $37 \mathrm{~g} / \mathrm{ft}^{3}$ \\
\hline Rhodium & $3 \mathrm{~g} / \mathrm{ft}^{3}$ \\
\hline Size (diameter $\mathrm{x}$ length) & $33 \mathrm{x} 60 \mathrm{~mm}$ \\
\hline Number of cells/ square inch (cpsi) & 100
\end{tabular}

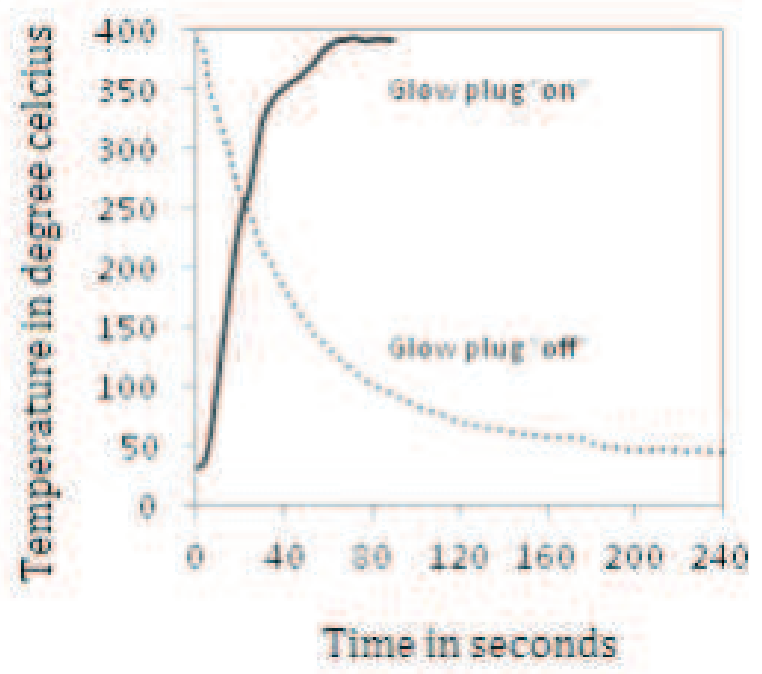

Figure 2: Glow plug surface temperature Source: Raja \& Arasu (2014)
An extra 12V, 80 Ah battery was used as power source to energize the glow plug for the exhaust gas ignition. The voltage and amperage for the glow plug were $11.9 \mathrm{~V}$ and $4.65 \mathrm{~A}$ respectively. To understand the characteristics of the glow plug, it was energized continuously by battery and its surface temperature was measured in still air condition after installing the glow plug in the exhaust pipe. At about 60 seconds, it reached the highest temperature $\left(390^{\circ} \mathrm{C}\right)$ and remained constant. At this point of time, power supply was cut and the surface temperature was measured. At about 200 seconds, it reached almost a constant value of $50^{\circ} \mathrm{C}$. The variation of glow plug surface temperature with time during on and off conditions is shown in Figure 2 (Raja \& Arasu, 2014).

\section{Results and discussion}

\section{3a) Phase 1 experiments - no modifications to the exhaust system}

The variations of exhaust emissions $\left(\mathrm{CO}, \mathrm{HC}, \mathrm{CO}_{2}\right.$, $\mathrm{O}_{2}$ and $\mathrm{NO}_{\mathrm{x}}$ ) and exhaust temperature with time in seconds are shown in Figure 3. It illustrates the sole effect of gasoline ethanol blends on cold start emissions in the absence of EGI and a catalytic converter. On comparison with neat gasoline, all blends showed reduction in $\mathrm{CO}, \mathrm{HC}, \mathrm{NO}_{\mathrm{x}}$ emissions and exhaust temperature. But there was an increase in $\mathrm{O}_{2}$ and $\mathrm{CO}_{2}$ emissions. The reduction in $\mathrm{CO}$ and $\mathrm{HC}$ emissions is due to the excess oxygen present in ethanol structure and this is confirmed by the increase in $\mathrm{CO}_{2}$ and $\mathrm{O}_{2}$ emissions. The reason for reduction in exhaust gas temperature is the higher latent heat of vaporization of blends compared to that of neat gasoline. Normally, $\mathrm{NO}_{\mathrm{x}}$ emissions are formed due to both oxygen availability and higher combustion temperature. Here, a drop in combustion temperature (inferred from exhaust temperature) plays a dominant role for reduction in $\mathrm{NO}_{\mathrm{x}}$ emissions though oxygen content is in excess. Despite the fact that $\mathrm{NO}_{\mathrm{x}}$ emissions are reported to be insignificant during cold-starts of gasoline and diesel fuelled engines (Weilenmann et al., 2005), its variation with ethanol percentage in the blend is presented here to understand the effect of fuel, EGI and the catalytic converter.

$\mathrm{CO}$ and $\mathrm{HC}$ emissions generally decrease with higher oxygen content and higher combustion temperature. With gasoline-ethanol blends, oxygen percentage in the exhaust is increased and combustion temperature is decreased. Therefore, the factor which reduces $\mathrm{CO}$ emissions with E5 and E10 is higher oxygen availability and the factor which increases CO emissions with E15 and E20 is lower combustion temperature. The same reasoning holds good for the increase in $\mathrm{HC}$ emissions with E20 compared to that of E5, E10 and E15. To confirm these observations, experiments were conduct- 


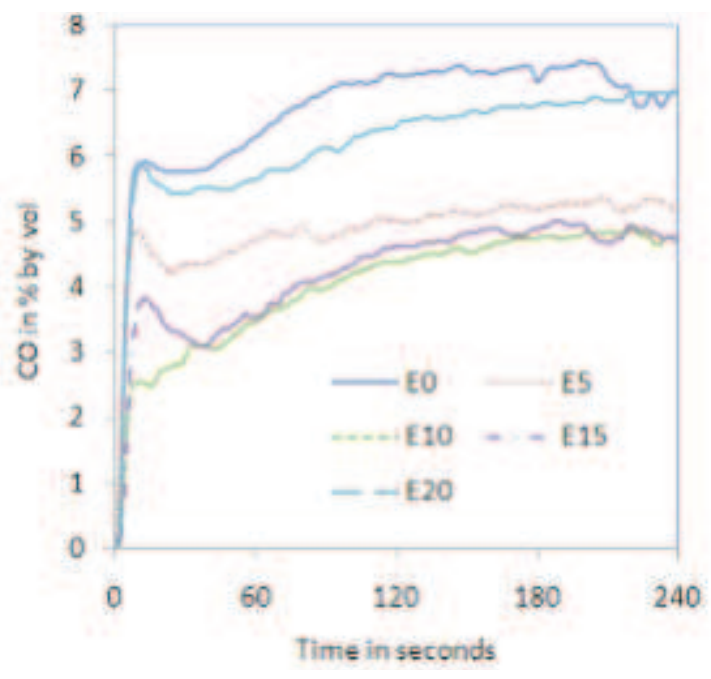

Figure 3a: Variation of $\mathrm{CO}$ with time

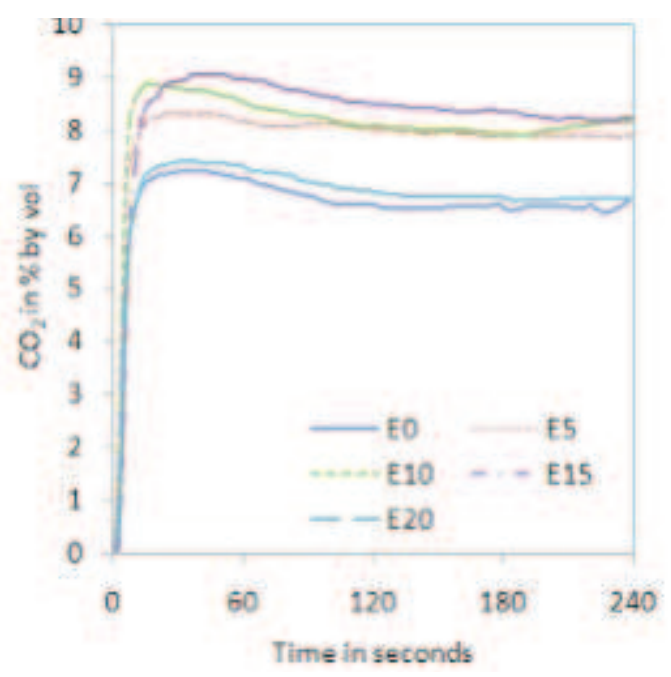

Figure 3c: Variation of $\mathrm{CO}_{2}$ with time

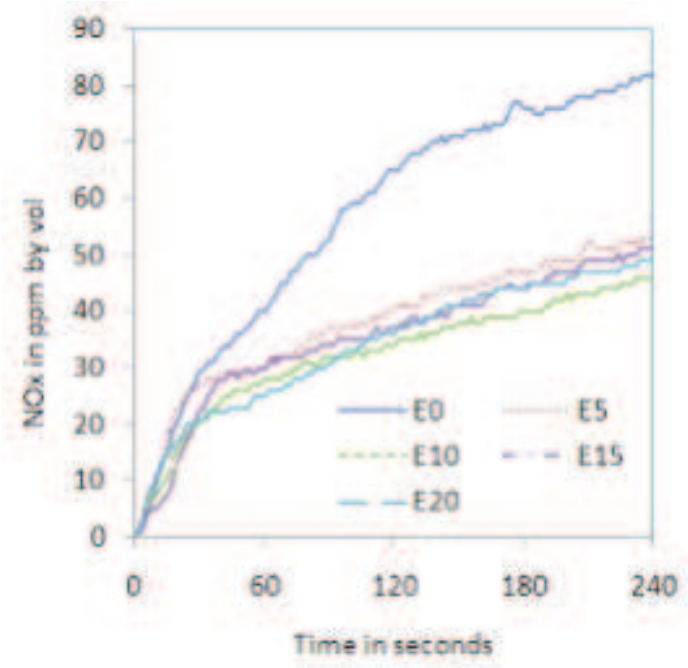

Figure 3e: Variation of $\mathrm{NO}_{x}$ with time

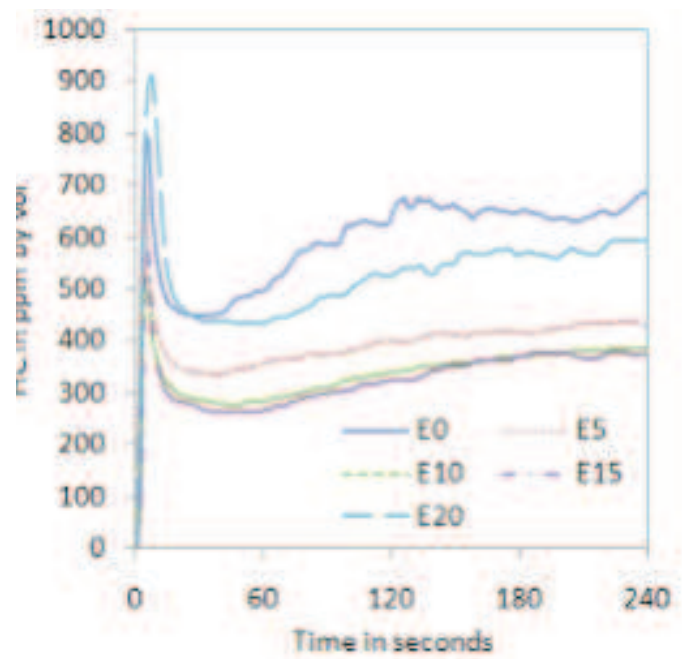

Figure 3b: Variation of $\mathrm{HC}$ with time

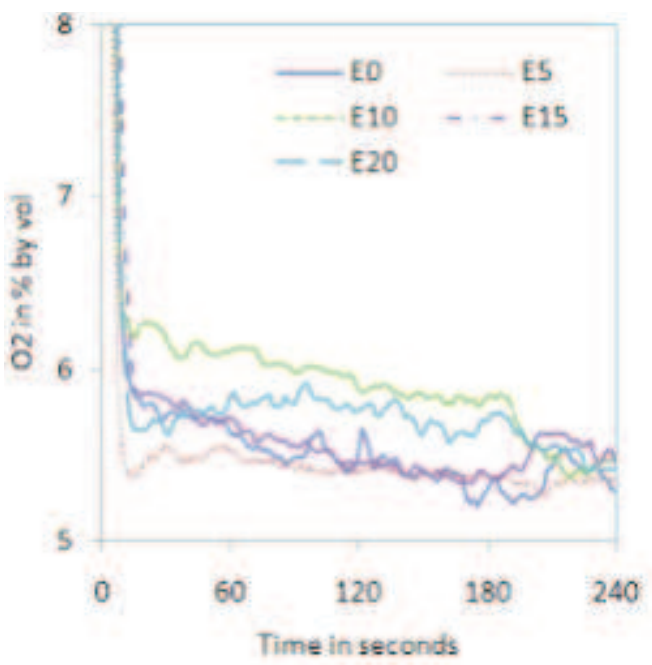

Figure 3d: Variation of $\mathrm{O}_{2}$ with time

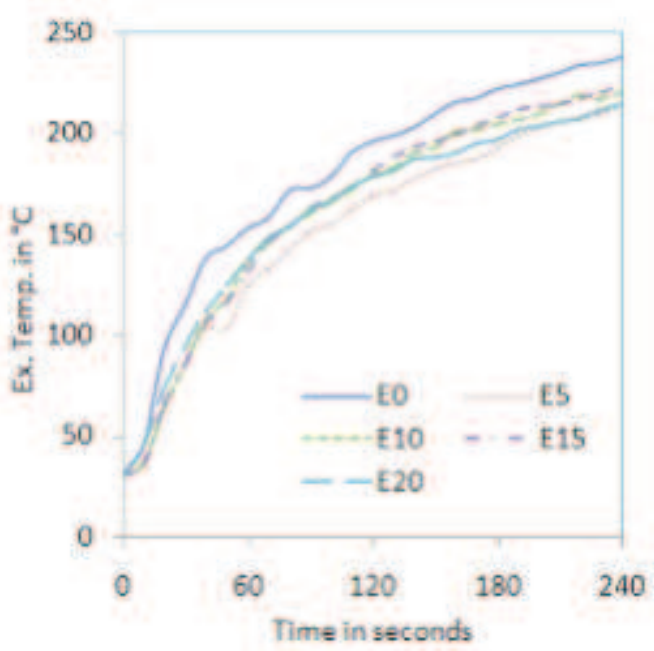

Figure 3f: Variation of Ex. Temp with time

Figure 3: Cold start emissions and exhaust temperature of phase 1 experiments 


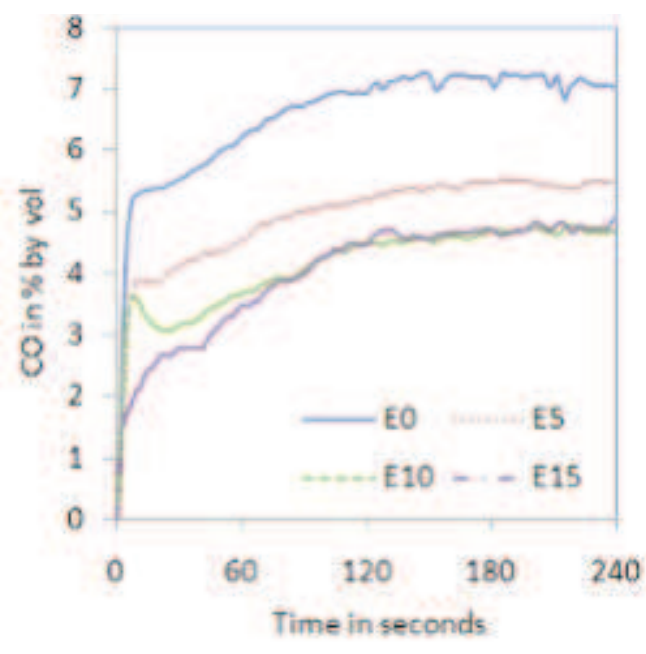

Figure 4a: Variation of $\mathrm{CO}$ with time

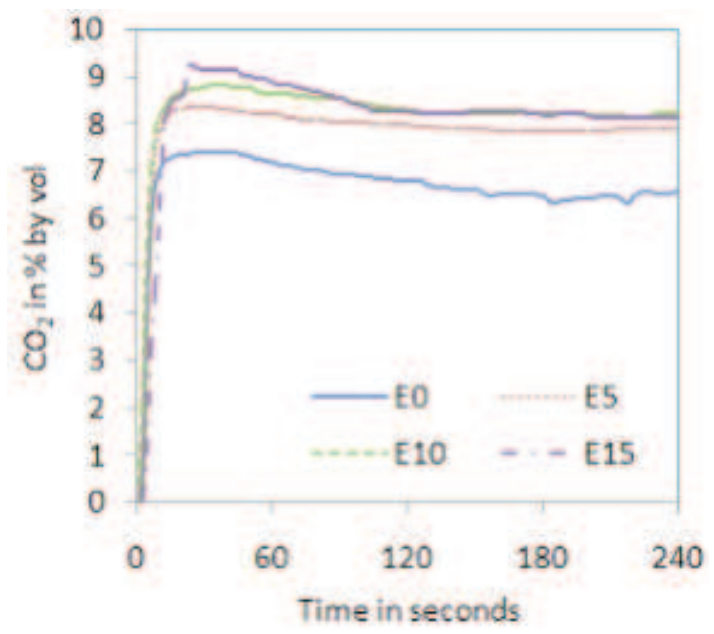

Figure 4c: Variation of $\mathrm{CO}_{2}$ with time

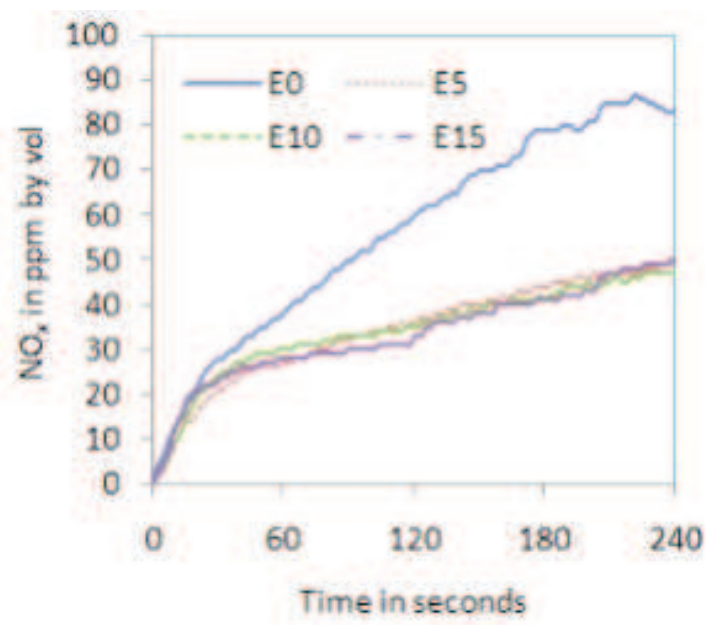

Figure 4e: Variation of $\mathrm{NO}_{x}$ with time

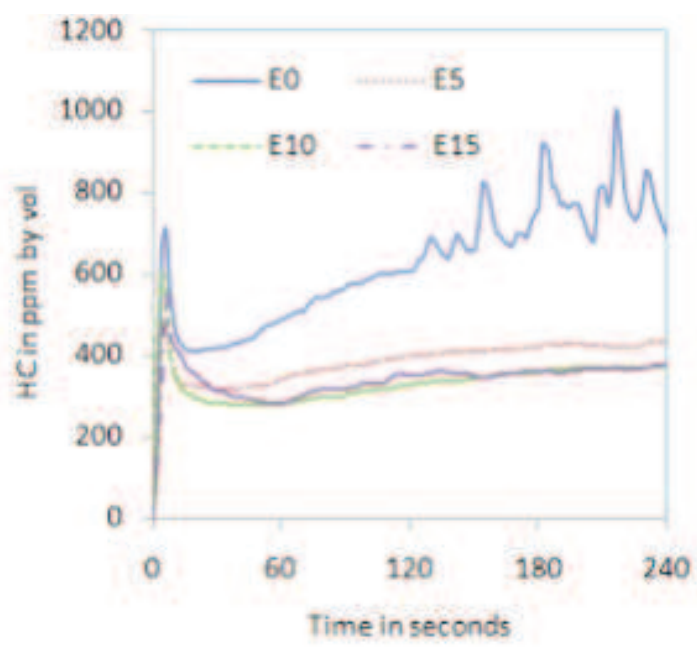

Figure 4b: Variation of $\mathrm{HC}$ with time

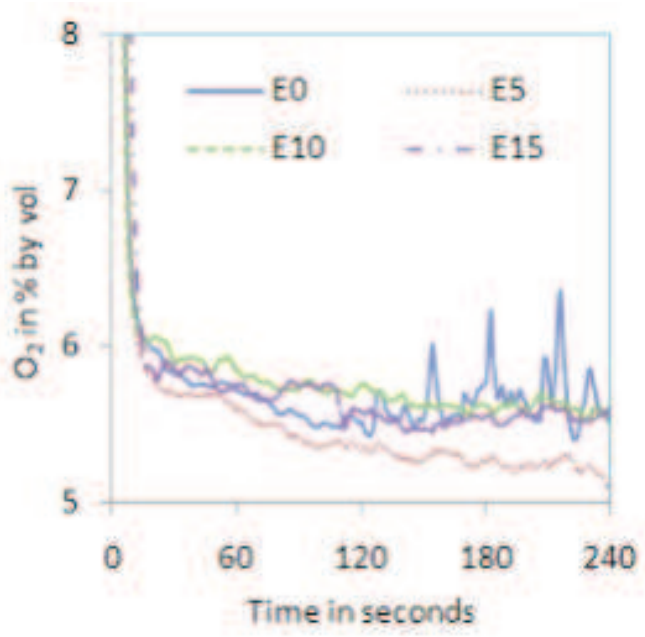

Figure 4d: Variation of $\mathrm{O}_{2}$ with time

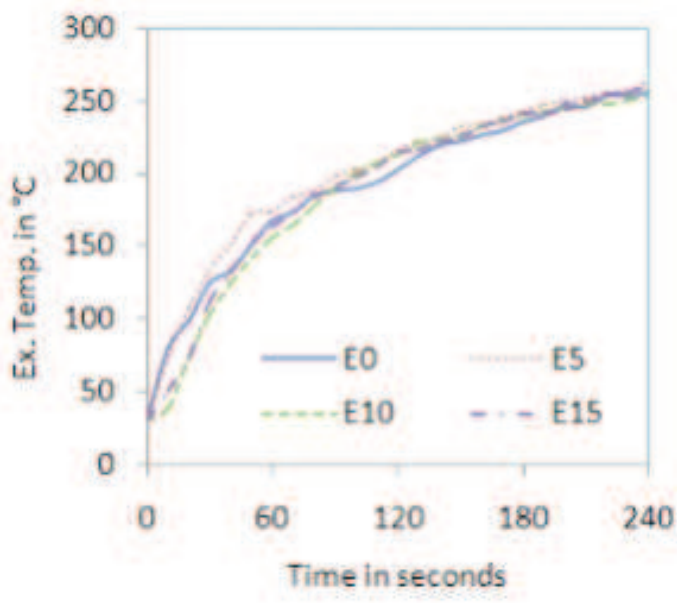

Figure 4f: Variation of Ex. Temp with time

Figure 4: Cold start emissions and exhaust temperature of phase-2 experiments 


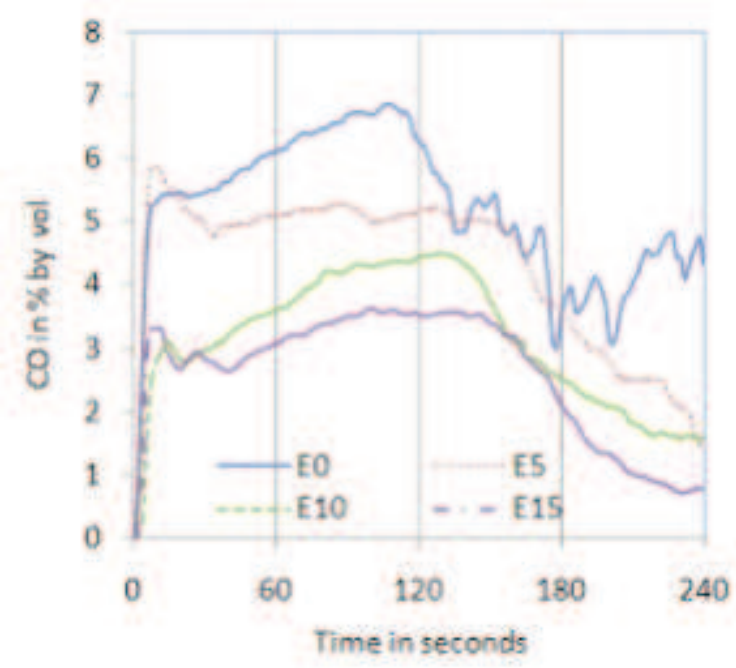

Figure 5a: Variation of $\mathrm{CO}$ with time

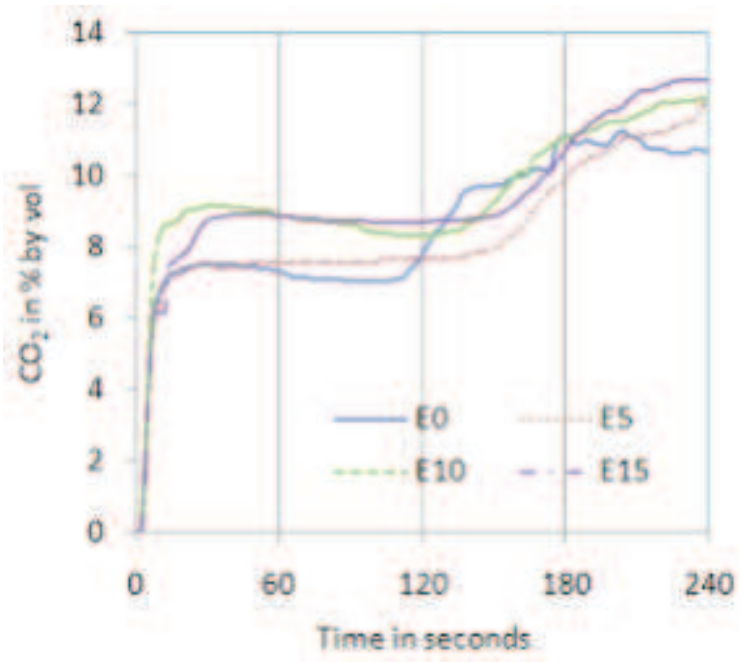

Figure 5c: Variation of $\mathrm{CO}_{2}$ with time

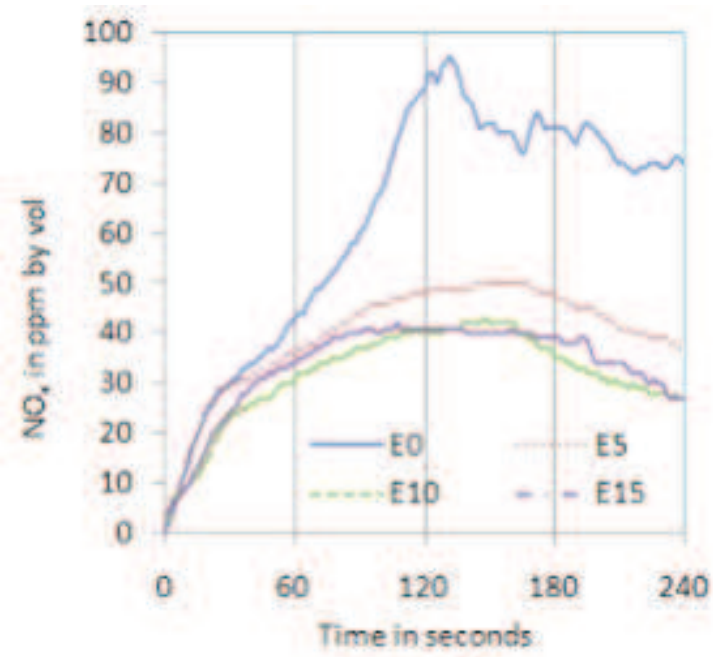

Figure 5e: Variation of $\mathrm{NO}_{x}$ with time

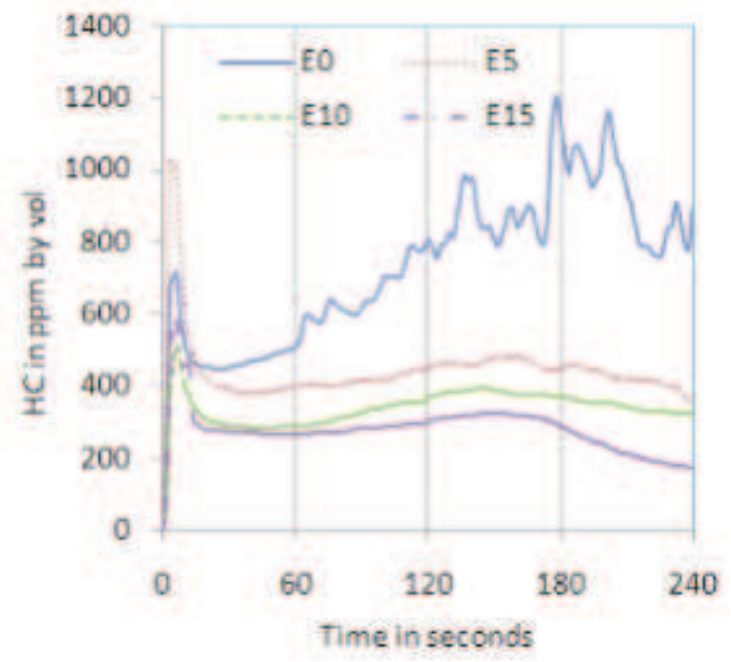

Figure 5b: Variation of $\mathrm{HC}$ with time

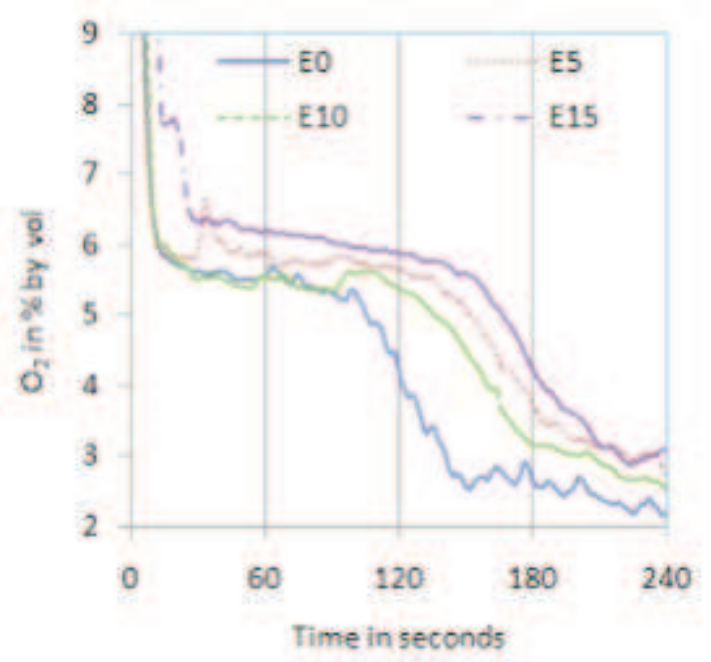

Figure 5d: Variation of $\mathrm{O}_{2}$ with time

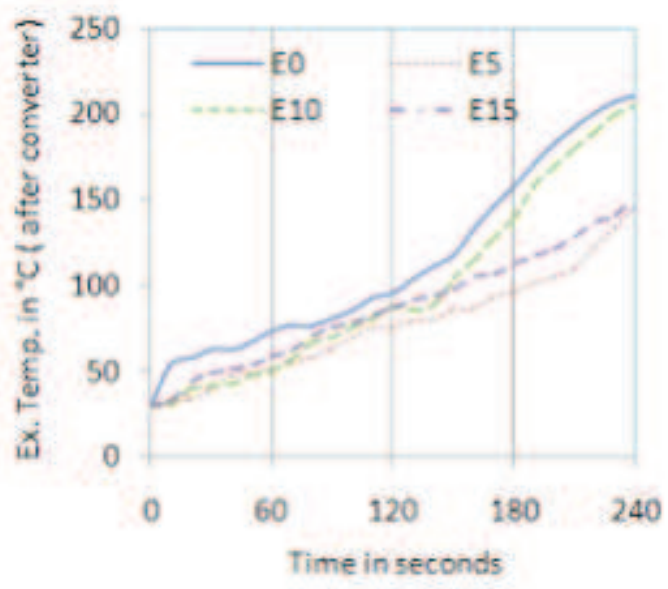

Figure 5f: Variation of Ex. Temp (after converter) with time

Figure 5: Cold start emissions and exhaust temperature of phase-3 experiments 
ed with E25 which led to very high amounts of CO and $\mathrm{HC}$ emissions. The magnitudes were about 50 $-75 \%$ higher (not shown in this paper) than those measured using neat gasoline and moreover unstable engine operation was noticed. This may be attributed to flame quenching and misfiring during combustion of E25 blend-air mixture. Hence, results are presented up to E20 in this paper. Taking average of $\mathrm{CO}$ and $\mathrm{HC}$ emissions for 4-minutes, highest reduction in CO $(40 \%)$ was observed with E10 and highest reduction in $\mathrm{HC}(44.8 \%)$ was observed with E15, as shown in Figures 6 and 7 respectively.

\section{3b) Phase 2 experiments - Impact of EGI}

As E5, E10 and E15 showed better results compared to E20, these three blends were considered in the second and third phase of experiments. The first phase of experiments was repeated with EGI in the second phase for E0, E5, E10 and E15. Figure 4 shows the effect of gasoline ethanol blends and EGI on cold start emissions in the absence of a catalytic converter.

All emissions and exhaust gas temperature were almost similar for E10 and E15 with EGI. Comparing the 4-min average $\mathrm{CO}$ emissions for different blends to that of neat gasoline, highest $\mathrm{CO}$ reduction of 39\% was observed for E15 and highest $\mathrm{HC}$ reduction of $46.5 \%$ was observed for $\mathrm{E} 10$ as shown in Figures 6 and 7 respectively. These reductions in $\mathrm{CO}$ and $\mathrm{HC}$ emissions reflect in the increase in $\mathrm{CO}_{2}$ and decrease in $\mathrm{O}_{2}$ as is shown in Figures.4c and $4 \mathrm{~d}$ respectively. The decrease in $\mathrm{CO}$ and $\mathrm{HC}$ is due to the partial combustion with the support of EGI. $\mathrm{NO}_{\mathrm{x}}$ emissions reduced with all blends in the same pattern as that without EGI which indicates that the effect of EGI is not predominant. The drop in exhaust gas temperature observed in the first phase of experiments is overcome with EGI in the second phase. Exhaust gas temperature of all blends was almost the same as that with neat gasoline as shown in Figure $4 \mathrm{f}$.

Comparing reductions in $\mathrm{CO}$ and $\mathrm{HC}$ emissions without EGI, a marginal improvement has been observed with EGI for almost all blends. The only positive change noticed was increase in exhaust temperature, which may help reduction of cold start $\mathrm{HC}$ and $\mathrm{CO}$ emissions by shortening the light off period of catalytic converter, if used.

\section{3c) Phase 3 Experiments - Catalytic convertor installed}

In order to understand the behaviour of a catalytic converter with gasoline-ethanol blends during the cold start period, a third phase of experiments was conducted and the results are shown in Figure.5. For all blends, $\mathrm{CO}$ emissions started to decrease after about 130 seconds whereas this cut-off time was about 105 seconds for neat gasoline. The delay in the activation of the catalysts is due to the lower exhaust gas temperatures with blends compared to neat gasoline. However, the highest percentage reduction in 4-min average $\mathrm{CO}$ and $\mathrm{HC}$ observed were 49.8 and 62.5 respectively for E15, as shown in Figures. 6 and.7 respectively. No positive effect was noticed in $\mathrm{HC}$ emissions for neat gasoline which reveal that the light off period for $\mathrm{HC}$ is longer than that for CO (Heywood, 1998). But with the blends, a slight reduction in $\mathrm{HC}$ was noticed after 150 seconds. The sudden increase in $\mathrm{CO}_{2}$ and sudden decrease in $\mathrm{O}_{2}$ at about 120 seconds confirm the action of the catalytic converter on $\mathrm{CO}$ and $\mathrm{HC}$ emissions. The decrease in $\mathrm{NO}_{\mathrm{x}}$ after about 120 seconds further ascertains the redox nature of the catalysts used. The oxidation of $\mathrm{CO}$ and $\mathrm{HC}$ to $\mathrm{CO}_{2}$ are exothermic reactions and the heat released increases exhaust gas temperature. The increase in the slope of the after-converter temperature curve at about 140 seconds (with E10 blend) confirms this effect and is shown in Figure $5 f$.

\section{3d) Consolidated comparison of 4-minute average $\mathrm{CO}$ and $\mathrm{HC}$ emissions}

The percentage reduction in 4-minute average $\mathrm{CO}$ and $\mathrm{HC}$ emissions compared to that of neat gasoline in each of these three phases are presented in Figures. 6 and. 7 respectively. (1 - without EGI and without catalytic converter, 2 - with EGI and without catalytic converter, 3 - without EGI and with catalytic converter).

\section{Conclusion}

Experiments were conducted in three phases on an air cooled four-stroke motorcycle S.I engine to (1) study the effect of gasoline-ethanol blends; (2) study the effect of exhaust gas ignition; and (3) study the effect of a catalytic converter on cold start emissions.

The impact of gasoline-ethanol blends alone ranging between $\mathrm{E} 5$ to $\mathrm{E} 20$ on cold-start emissions was studied in first phase experiments. E10 showed highest $\mathrm{CO}$ reduction (40\%) and E15 showed highest $\mathrm{HC}$ reduction (44.8\%). The same experiments were repeated with exhaust gas ignition (EGI) in the second phase to study the combined effect of gasoline-ethanol blends and EGI. Highest $\mathrm{CO}$ reduction of $39 \%$ was observed for E15 and highest HC reduction of $46.5 \%$ was observed for E10. From these two phases of experiments, it is concluded that gasoline-ethanol blends play a more important role in controlling cold start $\mathrm{HC}$ and $\mathrm{CO}$ emissions than the glow plug assisted exhaust gas ignition.

The combined effect of impact of a catalytic converter and gasoline-ethanol blends on cold-start emissions was studied through a third phase of experiments. It was found that a catalytic converter starts functioning after the light off period of 130 seconds or more for gasoline-ethanol blends where- 

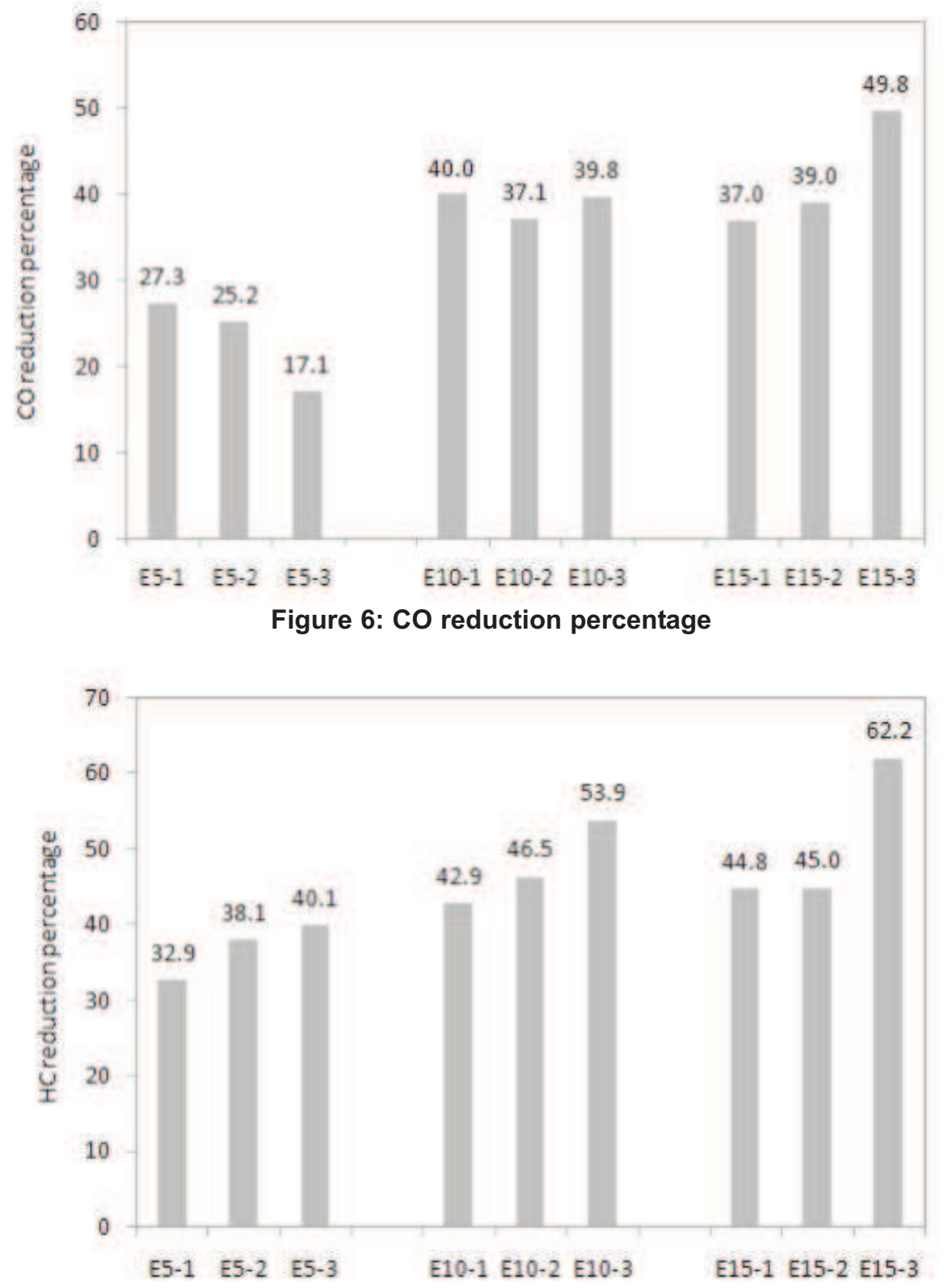

Figure 7: HC reduction percentage

as this light-off period was about 105 seconds for neat gasoline. However, the 4-min average $\mathrm{CO}$ and $\mathrm{HC}$ emissions decreased for all blends. The highest percentage reduction in $\mathrm{CO}$ and $\mathrm{HC}$ were observed to be 49.8 and 62.5 respectively for E15.

As most of the motorcycle engines manufactured before 2010 in India are running without a catalytic converter, use of E10/E15 blend and/or use of a catalytic converter are recommended for reducing cold start emissions.

\section{References}

Balki, MK., Sayin, C., and Canakci, M., (2012). The effect of different alcohol fuels on the performance, emission and combustion characteristics of a gasoline engine, Fuel, 115, pp. 901-906.
Bayraktar, H., (2005). Experimental and theoretical investigation of using gasoline-ethanol blends in spark-ignition engines, Renewable Energy, 30, pp. 1733-1747.

Botsaris, P.N., Bechrakis, D., and Sparis, P.D., (2003). An estimation of three-way catalyst performance using artificial neural networks during cold start, Applied Catalysis A: General, 243, pp. 285-292.

Canakci, M., Ozsezen, AN., Alptekin, E., and Eyidogan, M., (2013). Impact of alcohol-gasoline fuel blends on the exhaust emission of an SI engine, Renewable Energy, 52, pp. 111-117.

Chen, R.H., Chiang, L.B., Chen, C.N., and Lin, T.H., (2011). Cold-start emissions of an SI engine using ethanol-gasoline blended fuel, Applied Thermal Engineering, 31, pp. 1463-1467.

Clairotte, M., Adam, TW., Zardini, A.A., Manfredi, U., Martini, G., Krasenbrink, A., Vicet, A., Tournié, E., and Astorga, C., (2013). Effects of low temperature 
on the cold start gaseous emissions from light duty vehicles fuelled by ethanol-blended gasoline, Applied Energy, 102, pp. 44-54.

Eyidogan, M., Ozsezen, A.N., Canakci, M., and Turkcan, A., (2010). Impact of alcohol-gasoline fuel blends on the performance and combustion characteristics of an SI engine, Fuel, 89, pp. 2713-2720.

Favez, J.Y., Weilenmann, M., and Stilli, J., (2009). Cold start extra emissions as a function of engine stop time: Evolution over the last 10 years, Atmospheric Environment, 43, pp. 996-1007.

Heywood, J.B., (1998). Internal Combustion Engine Fundamentals, McGraw-Hill Publications, New York, USA.

Horng, RF., and Chou, H.M., (2004). 'Effect of input energy on the emission of a motorcycle engine with an electrically heated catalyst in cold-start conditions', Applied Thermal Engineering, 24, pp. 2017 2028.

Iliyas, A., Zahedi-Niaki, M.H., Eic', M., and Kaliaguine, S., (2007). Control of hydrocarbon cold-start emissions: A search for potential adsorbents, Microporous and Mesoporous Materials, 102, pp. 171-177.

Leong, S.T., Muttamara, S., and Laortanakul, P., (2002). Influence of benzene emission from motorcycles on Bangkok air quality, Atmospheric Environment, 36, pp. 651-661.

Masum, B.M., Masjuki, H.H., Kalam, M.A., Fattah, I.M.R., Palash, S.M., and Abedin, MJ., (2013). Effect of ethanol-gasoline blend on NOx emission in SI engine, Renewable and Sustainable Energy Reviews, 24, pp. 209-222.

Poulopoulos, S.G., and Philippopolous, C.J., (2003). The effect of adding oxygenated compounds to gasoline on automotive exhaust emissions', Eng. Gas Turbine power, 125, pp. 344-350.

Pourkhesalian, AM., Shamekhi, A.H., and Salimi, F., (2010). Alternative fuel and gasoline in an SI engine: A comparative study of performance and emissions characteristics, Fuel, 89, pp. 1056-1063.

Raja, A.S., and Arasu, A.V., (2014). Control of cold start hydrocarbon emissions of motor bike engine by gasoline-ethanol blends and intake air heating, Journal of Mechanical Science and Technology, 28, (4), pp. 1567-1573.

Sales, L.C.M., and Sodré, J.S., (2012). Cold start emissions of an ethanol-fuelled engine with heated intake air and fuel, Fuel, 95, pp. 122-125.

Santos, H., and Costa, M., (2008). Evaluation of the conversion efficiency of ceramic and metallic three way catalytic converters, Energy Conversion and Management, 49, pp. 291-300.

Singer, B.C., Kirchstetter, T.W., Harley, R.A., Kendall, G.R., and Hesson, J.M., (1999). A Fuel-Based Approach to Estimating Motor Vehicle Cold-Start Emissions, J. Air \& Waste Manage. Assoc., 49, pp. 125-135.

Spegar, T.D., Burke, D., and Lavan, L., (2012). Delphi's Heated Injector Technology: The Efficient Solution for Fast Ethanol Cold Starts and Reduced Emissions, SAE Technical paper 2012-01-0418.

Thring, R.H., (1983), Alternative fuel for spark-ignition engines', SAE Paper 831685.

Turner, D., Xu, H., Cracknell, R.F., Natarajan, V., Chen, X., (2011), Combustion performance of bio-ethanol at various blend ratios in a gasoline direct injection engine, Fuel, 90, pp. 1999-2006.

Twigg, M.V., (2006). Roles of catalytic oxidation in control of vehicle exhaust emissions, Catalysis Today, 117, pp. 407-418.

Twigg, M.V., (2007). Progress and future challenges in controlling automotive exhaust gas emissions, Applied Catalysis B: Environmental, 70, pp. 2-15.

Weilenmann, M., Soltic, P., Saxer, C., Forss, A.M., and Heeb, N., (2005). Regulated and non-regulated diesel and gasoline cold start emissions at different temperatures, Atmospheric Environment, 39, pp. 2433-2441.

Yang, H.H., Hsieh, LT., Liu, H.C., Mi, H.H., (2005). Polycyclic aromatic hydrocarbon emissions from motorcycles, Atmospheric Environment, 39, pp. 17-25.

Received 18 August 2014; revised 23 March 2015 